\title{
Family Experience during Patient Assistance Process in General Intensive Care Unit: A Phenomenology Study
}

\author{
Dwi Safitri ${ }^{1 *}$ (D) Anna Kurnia ${ }^{2}$ (D) , Much Al Jihad ${ }^{3}$ (D) \\ ${ }^{1}$ Department of Critical and Emergency Nursing, Faculty of Health, Muhammadiyah University, Semarang, Indonesia; \\ ${ }^{2}$ Department of Medical Surgical Nursing, Faculty of Health, Muhammadiyah University, Semarang, Indonesia; ${ }^{3}$ Department of \\ Community Nursing, Faculty of Health, Muhammadiyah University, Semarang, Indonesia
}

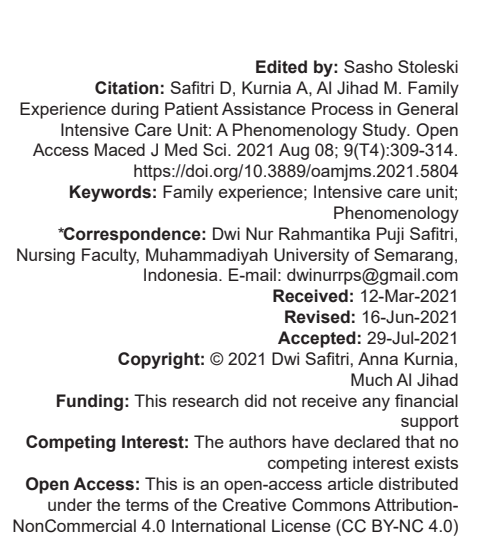

Introduction

Intensive care unit (ICU) treatment can lead to fear, sadness, anxiety, stress, and panic in the family [1]. A strange environment, visit regulation, unstable emotional, and daily activity changes are stressors for the family in ICU [2]. Family role as active presence, protector, facilitator, historian, and coaching makes it impossible for the family to be separated from treatment processes [3]. In addition, family participation can reduce the duration of stay (length of stay) for patients from 3.2 to 5.3 days and reduce the risk of repeated admission [4]. Family decision-making is often granted because patients suffer loss of consciousness or critical condition [5], processes [3]. Decision-making authority is also given by family because patients experience loss of consciousness or critical condition [5]. The important role of this family makes them always have to stay in the hospital. These condition bring new problems to the family.

Based on the researcher's experience in ICU treatment, families face a number of circumstances and difficult conditions, such as shock and fear when they get a call, fear of facilities inside the room, a feeling of confusion about the patient's condition, and others. Family anxiety, depression, and stress have occurred after the $1^{\text {st }}$ day of care in ICU [6], [7], [8]. Extreme visits control, lack of ICU team contact, incomprehensive medical patient knowledge, and volatility of the patient's condition have triggered family depression and sadness [9]. These stress factors make the family unable to make its own decisions requiring nurse or medical assistance.

ICU treatment also impact in daily activity, such quantity and quality of sleep, is changing. Literature found that family experiences sleep disturbances [11], [12] induced by anxiety, stress, and fear [13]. Decline in quality and quantity of sleep disturbances may lead to disruption of family functional status [14], [15]. Information on different ICU treatment procedures for other units [16] and information related to the development of a patient condition [13], it can improve the quality of family sleep. It could increase the quality of family sleep.

ICUs time treatment experiences in three phases [18]. The first phase gives the feeling of shock and disbelief that disorientation is progressing and that medical interventions, equipment, and alien culture in ICU are difficult to adapt for the second phase. Third step, family experience involves the awareness and appreciation of the needs of the patient, the ability to better understand the situation of the patient, the current 
culture of ICU, and decision-making. Different basic reasons reveal that experience is divided by contact between health workers, the families of patients, the emotional experience (feeling love), and the point of view of health workers and patients [18].

Patient ICU treatments offer different perceptions and observations of each process when patients join the ICU before they return home. The theme studied was confined in Indonesia. Based on the above scenario, researchers are interested in performing family experience research during the patient assistance process. The aim of this study is to provide an in-depth illustration of what is observed, felt, and interpreted by the family during the ICU patient care process. The research is expected to provide an understanding of family experiences during the process of assisting patients in the Intensive Care Unit for nurses, so that it can be used as a concept to develop nursing care, especially in family center care.

\section{Methods}

\section{Design, sample, and ethics}

This research uses a qualitative framework with a phenomenological approach to characterize and understand family experience in assisting ICU patients. Purposive sampling was used to recruit participants [19] based on family status, to interact in "Bahasa" and to follow patients for at least $24 \mathrm{~h}$. Participants were provided with all information on research purposes and were also asked to thoroughly read the informed consent form, to enable them to ask questions, and to sign their interest in the study. Recruitment continued until data saturation was achieved. In this study, the data saturation is obtained from the nine participants with three participants dropped out from the study. Ethical approval was received from the ethic committee of Dr. Hasan Sadikin Central General Hospital where the research was performed. This research was performed in the ICU of the Dr. Hasan Sadikin Central General Hospital. Ethical approval was issued after discussion and assessment of this research by the ethics committee.

\section{Methods and data collection}

In-depth interview, an open-ended interview was performed and digitally recorded. Open-ended questions with probes designed to examine and further analyze the results of the interview to clarify [20]. Family interviews began - "Tell me about your experience in assisting ICU patients." - Participants were enrolled before new knowledge was available, data saturation was reached and was adequate to explain the phenomenon of family experience during the course of the interview.
After the interviews, audio tapes were transcribed verbatim. Field notes were taken during the interviews and a reflective journal was kept during the study process. Repeat and confirmation of the collected data were noted for participant. After acquiring a significant phrase, the researchers formulate the significance of each of these statements and see an example of the study phenomenon. The recorded interviews were then transcribed by the researchers after the interviews were finished and keywords, challenging words and nonverbal phrases were recorded during the interview.

\section{Data analysis}

Colaizzi approaches have been used to view and appreciate the significance of family interactions. Following the Colaizzi study, the data began by reading all the transcripts repeatedly and looking at the statements relevant to the phenomenon. Then, the data are formulated by the context and classified to the theme. The theme will be organized and defined to explain the fundamental structure of the phenomenon. The final step of the study is to verify the classification of the participants [21], [22]. Finally, the critical interpretation of family experience contained seven themes.

\section{The validity of the data}

Reliability of data in qualitative research consists of authenticity, reliability, transferability, and compliance [23]. This analysis carried out credibility by transcripting the recording interviews with their superiors and then evaluated them. Researchers made a meeting with participants to explain the compatibility of the term while interviewing the transcript (validation) process. Credibility is also carried out by researchers by mastering related knowledge qualitative methods, especially with a phenomenological approach. Transferability was accomplished by posing the same interview questions to the participants randomly form the population and then testing if the responses from the participants and the researchers were the same. Dependability was achieved through the verification phases of research involving external reviewers who were researchers' supervisors. In addition, researchers were the primary interviewer for all participants so that the accuracy of the collective data could be maintained.

\section{Resulted}

Three themes emerged from thematic analysis of the participant's narrative. These themes are explained with a description of the theme. The quotes used to provide a clear illustration of characteristic in theme. These themes were chosen in accordance with the objective of this 
research. These themes describe the family experience while accompanying patients in the ICU.

\section{Physically and psychologically tired}

Family feel physically exhausted because they have been supporting the patient for a long time with no room for rest. Participants felt physically drained as a result of feeling wary of patient death threats, confusion, sadness, and other things. It caused emotional feeling more deeply. Some participant said,

"My body and mind are tired..." (P1)

"My mind is getting low, so terrible, no one want it... i am so tired think about it" (P6)

Disruption of rest and diet can cause family health problems. Furthermore, an unhealthy mental disorder such as terror, anxiety, depression, and stress affects a healthy lifestyle such as changes in appetite and sleep disorders that make the family feel tired [11]. Based on the phrase of the family above the theme, "physically exhausted" comes from feeling tired of the body and mind due to accompanying patient for a long time. The participants were exhausted because the room was not easy to sleep. It was attributed to a drop in the quantity and quality of sleep. Various emotional conditions simultaneously made family felt more pain than patient did.

"I still cannot sleep tightly... it's sleepless, and sometimes it causes headache... Moreover, I don't eat anything for 2 days..." (P4)

"It feels bad, especially a day after the operation, he does not wake up yet, it feels like I am the one who sick..." (P6)

\section{Good language is a medicine}

"Medicine" is notaliteral word, but rathera definitive term to be implicitly defined as "reducing psychological concern to the family (physical and psychological)." "Language" was a good family medical team mentality that could be a cure. It was said that the family was sicker than the patient, and good communication may be a medication (psychological healer) for the family. Good language in communication of medical team made family felt better, comfortable, and happy. Some participants said that it could be the cure of the sad, confused, fear, and stress feeling experienced by family.

"If the medical team gives us a good suggestion, it become like... a medicine. Then we feel calm..." (P2)

Good communication also made family felt calm although there was the bad news and comfortable feeling to refuse an action procedure.

"Doctor gives a nice explanation, it makes us calm even though we are not agree with the procedure..." (P1)

\section{Strengthen each other's companion}

ICU admission has taught families to be able to deal with a tough situation by adapting and handling problems. Family said that support was given not only by a friend but also by other family members. One of the adaptations created by families was to seek the help of other families in the waiting room to preserve their spirit, courage, and strength. Talking or kidding them made family entertained and momentarily could forget the problems they faced.

"We can say hello to each other, it is like... we are giving support and power to one another..." (P1)

"Especially, if a friend likes joking, we think that we can forget our problem..." (P6)

\section{Discussion}

The family is one that has a close friendship and an emotional connection between family members. During ICU hospitalization, the position of the family provides attention, love, creates protection and privacy, advocates, and ensures that patients receive good care [24]. This closeness of the family makes them fear when they die. They said fear emerged because the family thought that any ICU patient with an unstable condition could endanger patient life at any time. A research found that $91.38 \%$ of ICU patients' families said that they were scared if their loved one died [25]. Feeling wary of patient death threats, confusion, sadness, and other influent their rest time and appetite. Prolonged strong and sustained mental effort makes the family feel exhausted both physically and mental.

Fear of death correlated with prognosis of illness, instability, and chronic disease affecting the patient [8], [10]. Critical disease and precarious condition have made patients require a wide range of treatment facilities, but the use of this equipment is inversely proportional to the family's feeling. Mortality in ICU reached $31 \%$, while recovery was $69 \%$ [26]. This situation led to the impression that patients in this ward will have a bad outcome, and one sign of deteriorating condition is the use of certain treatment equipment. Shocked and unbelieved that their loved one should be admitted to ICU is one aspect that made the family feel fearful of getting medical equipment inside ICU [17]. However, this unfortunate experience will help families find an appropriate solution to their problems [27].

Patients' unstable condition involved more family attention, so they spent more time in the hospital. Moral obligation was a justification why the workers could not stay away and be easily reached while they were nested. Other reasons were to ensure that patients received the best care, to advocate for them to obtain the latest information on patient progress [24] and 
as informant patients [17]. Although disruptive family routines, actively assisted patients could be a source of family power [28]. In this research, the presence of patients means that they had to be in another room, but it was easy to reach the patient if needed. Some research has a different sense that staying ensures that the family will see or contact the patient and listen to the patients' will, support the patients' care, and advocate for the patient's needs [24], [29]. In comparison, 87.5\% of nurses said that family visits will be burdensome and detrimental to the treatment process [30].

Active involvement in ICU subjected the family to psychological and physical problems. Families were overwhelmed, nervous, frightened, and saddened by bad growth, life threatening, and medical equipment. Family felt depressed, anxious [12] and mentally unstable from the $1^{\text {st }}$ day of admission and persisted until the patient had moved out of ICU [8]. Long-term stress duration was directly related to the family's exhausted experience [11], [12]. Psychological conditions such as anxiety and stress may affect family habits such as appetite changes and sleep disturbances [11]. Based on the research findings, family seems to sleep but felt not sleep. Family sleep disorders included trouble sleeping, early waking, and feeling frustrated with sleep. Inadequate sleep and feeding caused the family to suffer from this form of flu and headache. Finding from the literature that the prevalence of sleep disorders reached $43.5 \%$, the families said that they experienced poor sleep quality at the hospital [12], [13].

Family member said that when health care providing support by good communication will help them through physical and psychological issues. It was translated as providing clarification and details through a good language and attitude [31], polite, precise, sensitive, and emphatic [32]. It helped families through challenging situations [16] and avoided worsening anxieties from developing into depression [33]. The previous research relevant with what family felt. They said sicker than the patient, and good communication may be a medication (psychological healer) for the family. Good and organized communication creates a happy feeling [34] and improved family involvement in decision making [35]. Good attitude and communication from nurse, made family calm and comfort even there was a bad news about patient.

From the phenomena, we know that family had a hard time during in hospital. The positive response made by families in facing difficult situations is to adapt. One of the adaptation efforts that families often do is to seek support in the form of advice and information to reduce the depression they are facing support [9]. Families with few supporters around them had higher levels of anxiety and depression than families with many supporters around them [12]. Neighborhood or friend support may also have a positive effect on the family by offering a solution based on their prior experience [36]. Family member support was also one of the social support elements that could offer relational and spiritual support to the family [37]. It can be concluded that everyone around the family can be the strength and enthusiasm for the family to go through difficult times while in the hospital

The strength of this research is the method and data analysis was used in accordance with the objectives of this research. During the research process, the researcher encountered limitation. The limitation is in the inclusion criteria which were not determined the minimum age limit to be a participant. It causes the researcher found one participant who had an age range away from other participants. The participant is 16 years old which have different of perspective and how to respond a situations with other participants, however, this participant can tell her experience felt very well so this participant still included in the research.

\section{Conclusion}

ICU has provided a different experience for every family. Families have different views regarding the situation at hand. Unpleasant experiences have an impact on the psychological and health of the family. On the other hand, pleasant experiences can be a motivation or reinforcement for the family. Health workers, particularly nurses, could be optimized to take advantage of the position of the family during care in the ICU such as be a source of strength for the family to endure difficult times while accompanying patients. In addition, nurses may be a family facilitator to pursue an adaptive solution to the problems experienced.

\section{Acknowledgments}

We are very grateful to the families who participated in this study.

\section{References}

1. Celik S, Genc G. Sleep problems, anxıety, depressıon and fatıgue on family members of adult intensıve care unit patıents. Int J Nurs Pract. 2016;22(5):512-22. https://doi.org/10.1111/ ijn. 12451 PMid:27357996

2. Farhan Z, Ibrahim K, Sriati A. Prediktor stres keluarga akibat anggota keluarganya dirawat di general intensive care unit. Majalah Kedokteran Bandung. 2014;46(3):150-4. https://doi. org/10.15395/mkb.v46n3.316 
3. McAdam JL, Puntillo K. Symptoms experinced by family members if patients in intensive care units. Am J Crit Care. 2009;18(3):20010; quiz 210. https://doi.org/10.4037/ajcc2009252 PMid:19411580

4. Al-Mutair AS, Plummer V, Brien AO, Clerehan R. Family needs and involvement in the intensive care unit: $A$ literature review. J Clin Nurs. 2013;22(13-14):1805-17. https://doi.org/10.1111/ jocn.12065

PMid:23534510

5. Huffines M, Johnson KL, Naranjo LL, Lissauer ME, Fishel MA, D'Angelo Howes SM, et al. Improving family satisfaction and participation in decision making in an intensive care unit. Crit Care Nurse. 2013;33(5):56-69. https://doi.org/10.4037/ ccn2013354

PMid:24085828

6. Azoulay E, Chaize M, Kentish-Barnes N. Involvement of ICU families in decisions: Fine-tuning the partnership. Ann Intens Care. 2014;4(1):37. https://doi.org/10.1186/s13613-014-0037-5 PMid:25593753

7. McAdam JL, Dracup KA, White DB, Fontaine DK, Puntillo KA. Symptom experiences of family members of intensive care unit patients at high risk for dying. Crit Care Med. 2010;4(38):1078-85. https://doi.org/10.1097/ccm.0b013e3181cf6d94

PMid:20124890

8. Płaszewska-Żywko L, Gazda D. Emotional reactions and needs of family members of ICU patients. Anaesthesiol Intensive Ther. 2012;44(3):145-9.

PMid:23110291

9. Turner-Cobb JM, Smith PC, Ramchandani P, Begen FM, Padkin A. The acute psychobiological impact of the intensive care experience on relatives. Psychol Health Med. 2016;21(1):20-6. https://doi.org/10.1080/13548506.2014.997763 PMid:25572144

10. Schmidt M, Azoulay E, Syndrome PC. Having a loved one in the ICU: The forgotten family. Curr Opin Crit Care. 2012;18(5):540-7. https://doi.org/10.1097/mcc.0b013e328357f141 PMid:22914431

11. Choi JY, Tate JA, Hoffman LA, Schulz R, Ren D, Donahoe MP. Fatigue in family caregivers of adult intensive care unit survivors. J Pain Symptom Manage. 2014;48(3):353-63. https:// doi.org/10.1016/j.jpainsymman.2013.09.018 PMid:24439845

12. Kao $\mathrm{Y}$, Chen $\mathrm{C}$, Chen $\mathrm{F}$, Lin $\mathrm{Y}$, Perng $\mathrm{S}$, Lin $\mathrm{H}$, et al. Effects of resourcefulness on sleep disturbances, anxiety, and depressive symptoms in family members of intensive care unit patients. Arch Psychiatric Nurs. 2016;30(5):607-13. https://doi.org/10.1016/j. apnu.2016.02.002

PMid:27654246

13. Day A, Haj-Bakri S, Lubchansky S, Mehta S. Sleep, anxiety and fatigue in family members of patients admitted to the intensive care unit: A questionnaire study. Crit Care. 2013;17(3):R91. https://doi.org/10.1186/cc12736 PMid:23705988

14. Corwin DS. Half of the family members of critically ill patients experience excessive daytime sleepiness. HHS Public Access 2015;40(8):1124-31.

15. Miyagi M, Miyatani M, Nakao T. Relation between choiceinduced preference change and depression. PLoS One. 2017;12(6):e0180041. pone. 0180041

16. Wigert H, Blom DM, Bry K. Parents experiences of communication with neonatal intensive-care unit staff: An interview study. BMC Pediatr. 2014;14(1):304. https://doi. org/10.1186/s12887-014-0304-5

\section{PMid:25492549}

17. Gill M, Bagshaw SM, Mckenzie E, Oxland P, Oswell D, Boulton D, et al. Patient and family member-led research in the intensive care unit: A novel approach to patient-centered research. 2016a;11(8):e0160947. https://doi.org/10.1371/ journal.pone. 0160947

PMid:27494396

18. Garrouste-Orgeas M, Périer A, Mouricou P, Grégoire C, Bruel C, Brochon S, et al. Writing in and reading ICU diaries: Qualitative study of families' experience in the ICU. PLoS One 2014;9(10):e110146. https://doi.org/10.1371/journal. pone. 0110146

PMid:25329581

19. Polit DF, Beck CT. Essentials of Nursing Research: Appraising Evidence for Nursing Practice. $8^{\text {th }}$ ed. China: Lippincontt Williams and Wilkins; 2014.

20. Afianti Y, Rachmawati IN. Metode Penelitian Kualitatif dalam Riset Keperawatan. Jakarta: Raja Grafindo; 2014.

21. Holloway I, Galvin K. Qualitative Research in Nursing and Healthcare; 2012. Available from: https://www.books.google. co.id/books. [Last accessed on 2020, Dec 02].

22. Creswell JW. Qualitative Inquiry and Research Design: Choosing among Five Approaches. Los Angeles, CA: Sage; 2013.

23. Behrend S, Riedemann NC, Gu A, Witte OW, Hartog CS Family satisfaction in the intensive care unit: $A$ quantitative and qualitative analysis. Intensive Care Med. 2013;39(6):1071-9. https://doi.org/10.1007/s00134-013-2862-7

PMid:23417207

24. McGraw SA, Truog RD, Solomon MZ, Sellers DE, Meyer EC. I was able to still be her mom-parenting at end on life in the pediatric intensive care unit. NIH Public Access 2013;13(6):617-8.

25. Urizzi F. Relatives' experience of intensive care: The other side of hospitalization. Rev Lat Am Enfermagem. 2007;15(4):598604. https://doi.org/10.1590/s0104-11692007000400012 PMid: 17923976

26. McAdam JL, Fontaine DK, White DB, Dracup KA, Puntillo KA Psychological symptoms of family members of high-risk intensive care unit patients. Am J Crit Care. 2014;21(9):386-93; quiz 394. https://doi.org/10.4037/ajcc2012582 PMid:23117902

27. Butler JM, Hirshberg EL, Hopkins RO, Brown M. Preliminary identification of coping profiles relevant to surrogate decision making in the ICU. PLoS One. 2016;11(11):e0166542. https:// doi.org/10.1371/journal.pone. 0166542

PMid:27835704

28. Adams JA, Anderson RA, Docherty SL, Tulsky JA, Steinhauser KE, Bailey DE Jr. Nursing strategies to support family members of ICU patients at high risk of dying. Heart Lung J Acute Crit Care. 2014;43(5):406-15. https://doi.org/10.1016/j. hrtlng.2014.02.001 PMid:24655938

29. Jacob M, Horton C, Rance-Ashley S, Field T, Patterson R, Johnson C, et al. Needs of patients' family members in an intensive care unit with continuous visitation. Am J Crit Care. 2016;25(2):118-25. https://doi.org/10.4037/ajcc2016258 PMid:26932913

30. Athanasiou BA, Papathanassoglou ED, Patiraki E, McCarthy MS Giannakopoulou M. Visitation in Greek intensive care. Am J Crit Care. 2014;23(4):326-33. https://doi.org/10.4037/ajcc2014986 PMid:24986174

31. Als LC, Nadel S, Cooper M, Vickers B, Garralda ME. A supported psychoeducational intervention to improve family mental health following discharge from paediatric intensive care: feasibility and pilot randomised controlled trial. 
BMJ Open. 2015;5(12):e009581. https://doi.org/10.1136/ bmjopen-2015-009581

\section{PMid:26715482}

32. Clark K, Milner KA, Beck M. Satisfaction with care delivered in the intensive care unit. Crit Care Nurse. 2016;36(6):e8-14. https://doi.org/10.4037/ccn2016276

PMid:27908955

33. Salins NS, Deodhar J, Muckaden MA. Intensive care unit death and factors influencing family satisfaction of intensive care unit care. Indian J Crit Care Med. 2016;20(2):97-103. https://doi. org/10.4103/0972-5229.175942

PMid:27076710

34. Omar AS, Sivadasan PC, Gul M, Taha R, Tuli AK, Singh R. Impact of fast-track discharge from cardiothoracic intensive care on family satisfaction. BMC Anesthesiol. 2015;15:78. https://doi. org/10.1186/s12871-015-0060-6

35. Butler AE, Hall $H$, Willetts G. Family experience and PICU death: A meta-synthesis. 2015;136(4):e961-73. https://doi. org/10.1542/peds.2015-1068

PMid:26371203 